\title{
Degradation of Textile Wastewater by Electrochemical Method
}

\author{
Prakash Kariyajjanavar ${ }^{1}$, Jogttappa Narayana ${ }^{1}$ and Yanjerappa Arthoba Nayaka ${ }^{2 *}$
}

${ }^{1}$ Department of P.G. Studies \& Research in Environmental Science, Kuvempu University, Jnana Sahyadri, Shankaraghatta,577451Karnataka, India ${ }^{2}$ Department of P.G. Studies \& Research in Chemistry, Kuvempu University, Jnana Sahyadri, Shankaraghatta, 577451 Karnataka, India

\begin{abstract}
The degradation of diluted textile effluent was studied by electrochemical technique. For electrochemical degradation, the graphite carbon electrodes were used as anode and cathode. Electrochemical behavior of effluent was performed with cyclic voltammetry in different $p^{H} 1$ to 11 using pencil graphite as working electrode. The potentials selected for the dyes were in the range $+0.8 \mathrm{~V}$ to $-0.4 \mathrm{~V}$. The voltammetric curve of effluent at $p^{H} 1$ shows cathodic peaks at $+0.3365 \mathrm{~V}$ and $+0.0613 \mathrm{~V}$ and anodic peaks at $+0.396 \mathrm{~V}$ and $+0.689 \mathrm{~V}$. During electrochemical degradation, the chromoporic groups and aromatic rings were destroyed. Decolourisation and degradation of the effluent was followed using UV-vis spectroscopy, LC-MS and COD measurements. The dyes present in the textile effluent were completely oxidised and degraded with graphite electrodes. The effect of initial $p^{H}$, supporting electrolyte and current density on the degradation of textile effluent was discussed.
\end{abstract}

Keywords: Carbon electrodes; Cyclic voltammetry; Electrochemical degradation; LC-MS; Textile effluent

\section{Introduction}

Textile wastewater includes a large variety of dyes and chemicals that make the environmental challenge for textile industry not only as liquid waste but also in its chemical composition [1]. Main pollution in textile wastewater came from dyeing and finishing processes. These processes require the input of a wide range of chemicals and dyestuffs, which generally are organic compounds of complex structure [2]. Effluent from most textile dyeing operations generally has a dark reddish-brown color that is aesthetically unpleasing when discharged to receiving waters [3] that include public sewers, ponds, rivers and irrigation lands [4]. Textile industries generate effluent at an average of $100-170 \mathrm{~L} \mathrm{Kg}^{-1}$ of cloth processed, which is characterized by strong color, high COD with wide variation in $p^{H}$ [5]. Major pollution load from the textile industry is from the various wet processing operations like scouring, bleaching, mercerizing, dyeing and the amount of composite effluent discharged from the textile mills varied from 1 to 10 million liters per day depending upon the quantity of cloth produced and various manufacturing processes employed [4].

Conventional biological treatment is the most efficient and economic way of reducing the environmental impact of the industrial effluents containing organic pollutants, but this technique is time consuming and cannot be employed for textile effluent, as textile effluent is recalcitrant to biodegradation. On the other hand, the physical adsorption is expensive and difficult for adsorbent regeneration. Further, biological and chemical methods generate considerable quantity of sludge, which itself requires treatment. Due to the large variability of the composition of textile wastewater, most of the traditional methods are becoming inadequate [6-8]. As environmental regulations become stringent, new and novel processes for efficient treatment of various kinds of wastewater at relatively low operating cost are needed. In this context, researchers are trying various alternative processes, such as electrochemical technique, wet oxidation, ozonization, photocatalytic method for the degradation of organic compounds. Among these advanced oxidation processes, the electrochemical treatment has been receiving greater attention in recent years due to its unique features, such as versatility, energy efficiency, automation and cost effectiveness $[9,10]$ and giving promising results $[11,12]$.
The electrochemical treatment of textile dye wastewater has also been studied using cast iron [13], boron doped diamond (BDD) [14,15], Pt/Ti [16,17], Ti/ $\mathrm{RuO}_{2}$ [18] Ti/Pt/Ir, active carbon fiber (ACF), stainless steel 304 [19] and graphite carbon electrodes [20]. In the past, graphite was frequently used as an anode for the electrochemical degradation of textile wastewater as it is relatively cheaper and gives satisfactory results [21]. The aim of this work was to test the feasibility of electrochemical method for the degradation textile effluent

\section{Experimental Part}

\section{Materials}

The textile effluent was collected from after dyeing process (concentrated) in textile industry Himatsingka Linens, Hassan, India. After bringing the laboratory the effluent was diluted with potable water for laboratory studies. All other chemicals used for experiments were of analytical grade reagents and obtained from $\mathrm{s} d$ fine chemlimited, Mumbai, India. Double distilled water was used to prepare the reagents. Cylindrical carbon electrodes (Chemical composition: graphite carbon + coke: $85 \%$ and ash $15 \%$ ) were obtained from Power Cell Battery India Limited. A digital DC power supply (AD 302S: 30V, $2 \mathrm{~A}$ ) was used as an electrical source.

\section{Instrumentation}

Electrochemical measurements: The electrochemical measurements were carried out for dye effluent using CHI660D electrochemical workstation ( $\mathrm{CH}$ Instruments Austin, USA) controlled by electrochemical software. A three electrodes system was used for the cyclic voltammetric experiments. The working electrode was highly

*Corresponding author: Yanjerappa Arthoba Nayaka, Department of Chemistry, School of Chemical Sciences, Jnana Sahyadri, Shankaraghatta - 577451 , Shivamoggga Dist., Karnataka, INDIA, Ph: 08282-256308(O), Mobile: 94488-55078, Fax: 08282-256255; E-mail: drarthoba@yahoo.co.in

Received November 28, 2010; Accepted March 01, 2011; Published April 22 2011

Citation: Kariyajianavar P, Narayana J, Nayaka YA (2011) Degradation of Textile Wastewater by Electrochemical Method. Hydrol Current Res 2:110. doi:10.4172/2157-7587.1000110

Copyright: (c) 2011 Kariyajjanavar P, et al. This is an open-access article distributed under the terms of the Creative Commons Attribution License, which permits unrestricted use, distribution, and reproduction in any medium, provided the original author and source are credited. 
polished, pencil graphite disc with an effective surface area of 0.002 $\mathrm{cm}^{2}$. A platinum wire and saturated calomel were used as counter and reference electrodes, respectively.

Electrochemical degradation studies: Figure 1 shows the experimental setup for the electrolysis. Graphite carbon electrodes of $4.5 \mathrm{~cm}$ length and $0.8 \mathrm{~cm}$ diameter were used as anode and cathode. The effective electrode area was $11.82 \mathrm{~cm}^{2}$. The supporting electrolytes such as $\mathrm{NaCl}$ and $\mathrm{Na}_{2} \mathrm{SO}_{4}$ were added to the electrolytic solution, which increases the conductivity of the dye effluent and reduces the electrolysis time. The solution was kept under agitation using magnetic stirrer.

UV-visible studies: A UV-Vis Spectrophotometer (ELICO, SL159) was employed to measure the optical density of (at $\lambda_{\max }=440 \mathrm{~nm}$ ) dye effluent before and after electrolysis. The decolourisation efficiency was calculated using the relation:

$$
\% E=\frac{A_{i}-A_{f}}{A_{i}} \times 100
$$

where, $A_{i}$ and $A_{f}$ are absorbance values of dyes solutions before and after treatment with respect to their $\lambda_{\max }$, respectively or $A_{i}$ and $A_{f}$ are initial and final COD values of the dye effluent, respectively.

$\mathbf{p}^{\mathrm{H}}$ and conductivity measurement: A water analyser (Systronics, Model-371) was used to measure the $p^{H}$ and conductivity of the dye effluent before and after electrolysis under different electrolysis conditions.

\section{Liquid chromatography-mass spectrometry studies (LC-MS)}

The extent of degradation of dye effluent was analyzed by LC-MS studies (LCMS-2010A, Shimadzu, Japan). The LC-MS was fitted with column C18. The mobile phase was methanol: water (90:10). The flow rate was $0.2 \mathrm{~mL} \mathrm{~min}^{-1}$ and the injection volume of dye was $5 \mu \mathrm{L}$. The dye solutions were injected into LC column before and after electrolysis. Analyses using ESI (electron spray ionization) interface were done under the same chromatographic conditions as described for the APCI (atmospheric pressure chemical ionization) analysis, except the guard column, which was not used in the ESI analysis.

\section{Results and Discussion}

\section{Voltammetry}

The cyclic voltammagrams of dye effluent (diluted) were recorded in $p^{H} 1$ to $p^{H} 11$ using pencil graphite as working electrode. The

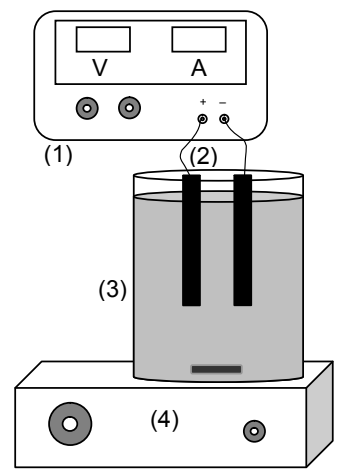

Figure 1: Schematic diagram of the experimental setup (1, DC power supply; 2 Electrode pair; 3, Electrolytic cell; 4, Magnetic stirrer.

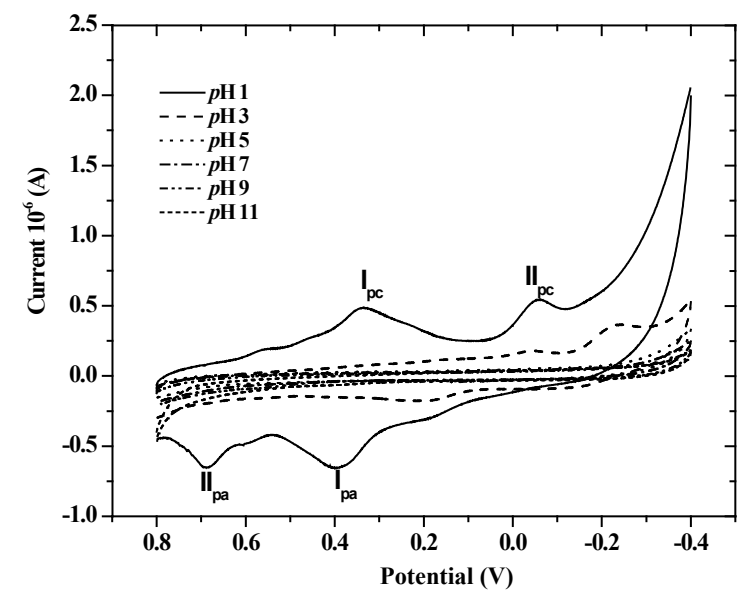

Figure 2: Cyclic voltammograms of dye effluent at different $p^{H}$ on PGE at a scan rate of $100 \mathrm{~m} \mathrm{Vs}^{-1}$
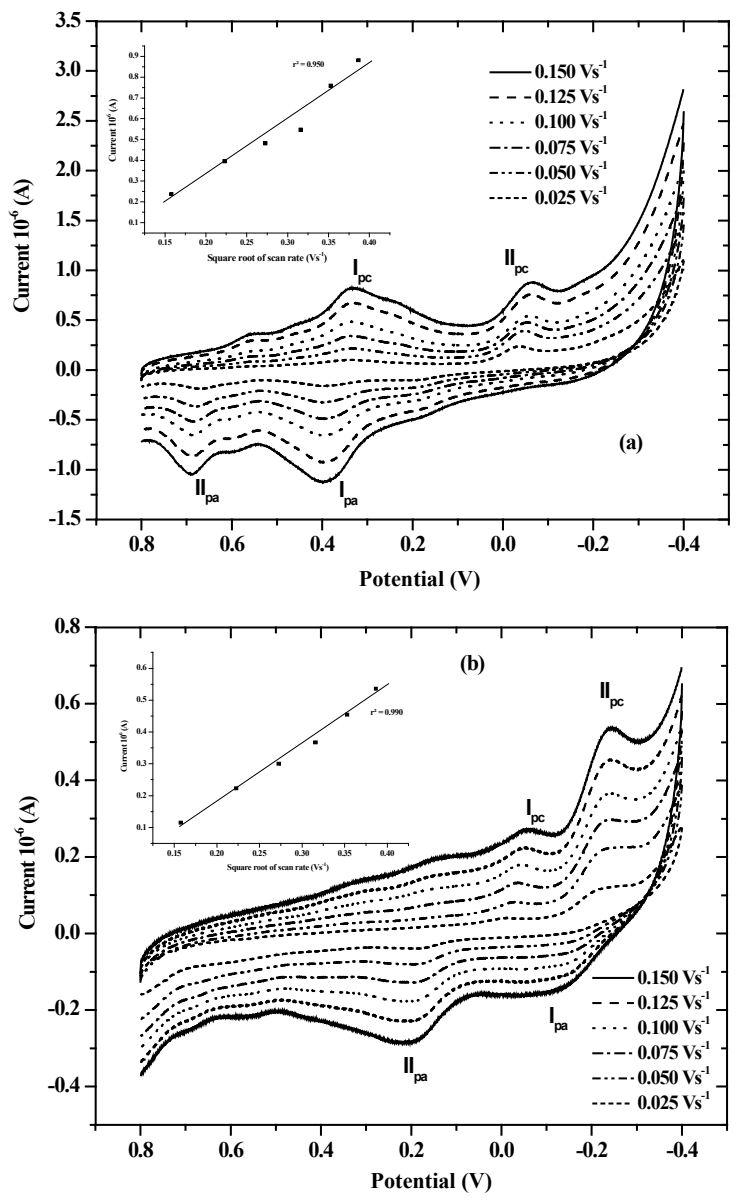

Figure 3: Cyclic voltammograms of dye effluent at (a) $p^{H} 1$ and (b) $p^{H} 3$ on PGE at different scan rate. Inset plots: linear relationship between the current and $u^{1 / 2}$

potential range selected was $+0.8 \mathrm{~V}$ to $-0.4 \mathrm{~V}$. The voltammetric curve of effluent shows cathodic peaks at $+0.3365 \mathrm{~V}\left(\mathrm{I}_{\mathrm{pc}}\right)$ and $+0.0613 \mathrm{~V}$ (II $\left.\mathrm{Ic}\right)$ in the forward scan and anodic peaks at $+0.396 \mathrm{~V}\left(\mathrm{I}_{\mathrm{pa}}\right)$ and $+0.689 \mathrm{~V}$ (II ${ }_{\mathrm{pa}}$ ) in reverse scan at $p^{H} 1$ (Figure 2). The reduction and oxidation 
peak observed in the voltammagrams $\left(\mathrm{I}_{\mathrm{pc}}\right.$ and $\left.\mathrm{I}_{\mathrm{pa}}\right)$ at $p^{H} 1$ attributed due to strong solution of $\mathrm{H}_{2} \mathrm{SO}_{4}$. The peaks $\mathrm{II}_{\mathrm{pc}}$ and $\mathrm{II}_{\mathrm{pa}}$ were attributed due to colour producing organic groups (chromophores) present in the dye effluent. By increasing $p^{H}$ of the solution reduction and oxidation peaks were shifted towards higher negative of potential range. In basic $p^{H}$ peaks were found to be disappeared, indicates that, the dye molecules present in the textile effluent was reduced at acidic $p^{H}$. These data are very much important to assess the feasibility of the electrochemical process for the degradation of dye effluent.

Figure $3 \mathrm{a}\left(\mathrm{at} p^{\mathrm{H}} 1\right)$ and Figure $3 \mathrm{~b}\left(\right.$ at $\left.p^{\mathrm{H}} 3\right)$ show the effect of scan rate on the cyclic voltammograms of dye effluent. The reduction peak current $\left(\mathrm{II}_{\mathrm{pc}}\right)$ increased linearly with square root of the scan rate $\left(v^{1 / 2}\right)$ over the range $0.025 \mathrm{~V} \mathrm{~s}^{-1}$ to $0.150 \mathrm{~V} \mathrm{~s}^{-1}$. Inset plots showed linear relationship. The correlation co-efficient $\left(\mathrm{r}^{2}\right)$ of dye effluent was found to be 0.950 and 0.990 for cathodic peak current at $p^{H} 1$ and $p^{H} 3$, respectively ( $\mathrm{II}_{\mathrm{pc}}$ ) indicates electrode process was diffusion controlled. The difference between the anodic peak and cathodic peak potentials, $\Delta \mathrm{E}_{\mathrm{p}}$ was increased with increasing scan rate.

\section{Influence of electrolytic conditions on dyes degradation}

Effect of initial $\mathbf{p}^{\mathrm{H}}$ : Solution $p^{\mathrm{H}}$ is one of the important factors that affect the performance of electrochemical process. Hence experiments were conducted to study the effect of $p^{H}$ on the degradation efficiency of

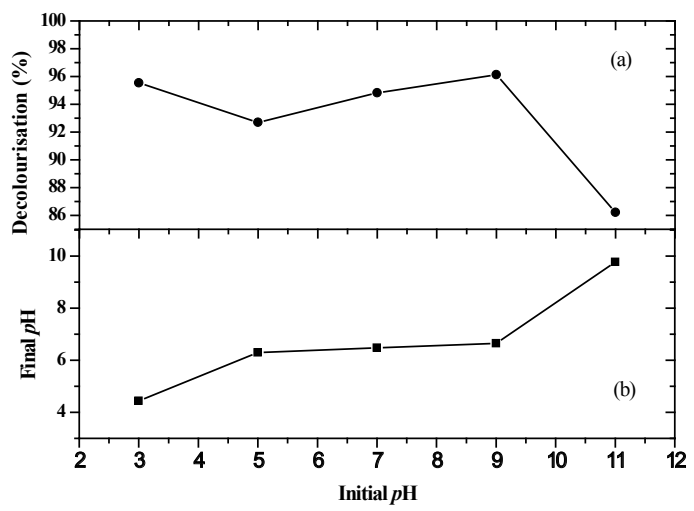

Figure 4: Effect of initial $p^{H}$ on (a) decolourisation efficiency and (b) final $p^{H}$.

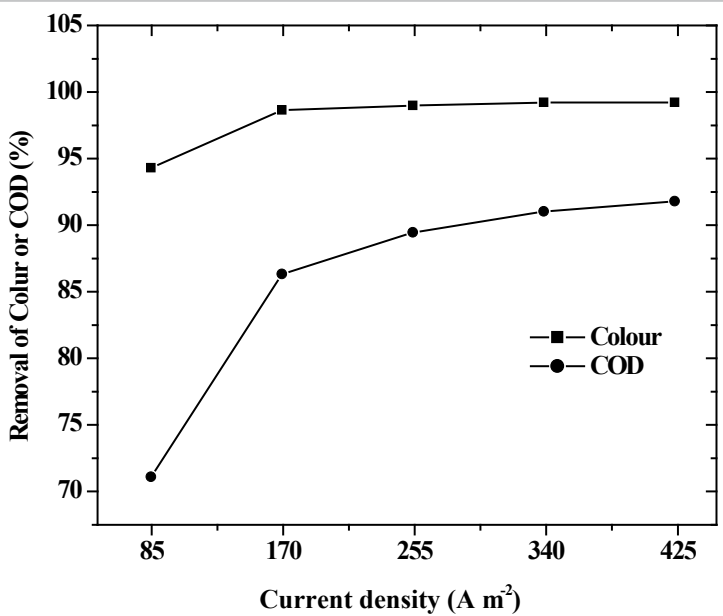

Figure 5: Effect of current densities on decolourisation and COD removal at optimal conditions.

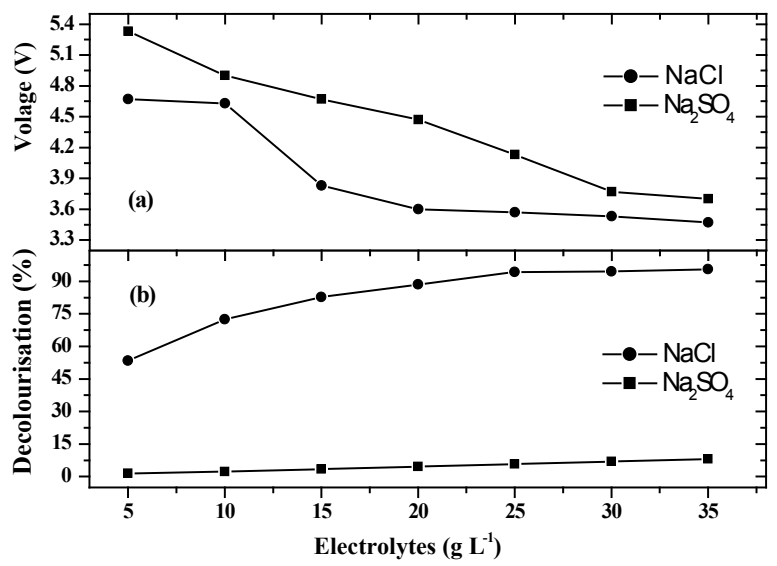

Figure 6: Effect of different supporting electrolyte and their concentration on decolouration of effluent.

textile effluent. A significant difference in the extent of decolourisation was noted when concentration of $\mathrm{NaCl}$ was at $25 \mathrm{~g} \mathrm{~L}^{-1}$. The initial $p^{\mathrm{H}}$ of the solution (3-11) was adjusted using $1 \mathrm{~N} \mathrm{H}_{2} \mathrm{SO}_{4}$ or $\mathrm{NaOH}$ [22]. The electrolysis was carried out at the current density of $170 \mathrm{Am}^{-2}$ for 4 hours with a textile effluent and at room temperature (315K). After electrolysis the results indicate that final $p^{H}$ was slight varied from acidic condition and decreased from basic conditions (Figure 4 ). The decolouration efficiency of dye effluent was found percentage of 95.54 $\%$ in acidic $p^{H}-3$ and at initial $p^{H}$ was 11 the decolouration efficiency was only the percentage of $86.22 \%$. It indicated that the degradation of dye effluent in acidic solution is higher than that of in the basic media. Therefore the optimum $p^{H} 3$ was maintained in subsequent experiments.

Effect of current density: Current density is a very important variable in electrochemical engineering. As shown in the Figure 5, both the colour and COD removal efficiency was increased by increasing the applied current density $\left(85,170,255,340\right.$ and $\left.425 \mathrm{~A} \mathrm{~m}^{-2}\right)$ the results may attributed to the increased oxidant such as: chlorine/hypochlorite, hydroxyl radicals at higher current densities. The hydroxyl radical adsorbed on the active sites at the anodic surface of the graphite carbon increases with current density, which in turn would enhance the rate of electro-oxidation of dye molecule present in the effluent. Further increase in the current density did not have much effect on decolourisation, which can be attributed to the fact that increasing current density increases over potential required for the generation of oxidants [23]. At the same time, more energy will be consumed at higher current density applied. Therefore, the optimal current density for the successive electrochemical degradation of dye effluent was 170 $\mathrm{A} \mathrm{m}^{-2}$.

\section{Effect of supporting electrolytes}

Figure 6 show the effect of supporting electrolytes $(\mathrm{NaCl}$ and $\mathrm{Na}_{2} \mathrm{SO}_{4}$ ) and their concentration of on decolourisation efficiency. As can be seen from the Figure when $\mathrm{Na}_{2} \mathrm{SO}_{4}$ was substituted by $\mathrm{NaCl}$, the decolourisation efficiency increased with a subsequent decrease in the applied voltage. From this observation it concluded that the introduction of $\mathrm{NaCl}$ as electrolyte can enhance the degradation efficiency and shortens electrolysis time, which may be attributed due to the reaction between the electro generated chlorine/hypochlorite 
and the dye molecule present in the effluent. The possible mechanism of electrochemical degradation is given bellow:

$$
\begin{aligned}
& \text { Anode reaction: } 2 \mathrm{Cl}^{-} \rightarrow \mathrm{Cl}_{2}+2 \mathrm{e}^{-} \\
& \text {Cathode reaction: } 2 \mathrm{H}_{2} \mathrm{O}+2 \mathrm{e}^{-} \rightarrow \mathrm{H}_{2}+2 \mathrm{OH}^{-}
\end{aligned}
$$$$
\text { Bulk solution reaction: } \mathrm{Cl}_{2}+\mathrm{H}_{2} \mathrm{O} \rightarrow \mathrm{HOCl}+\mathrm{HCl}
$$

$$
\mathrm{HOCl} \rightarrow \mathrm{H}^{+}+\mathrm{OCl}^{-}
$$

The generated hypochlorite ions act as main oxidizing agent in the pollutant degradation [5] and were classified as indirect electrooxidation of pollutant. Moreover, the increased $\mathrm{NaCl}$ results in a decrease in the operating voltage at constant current density (Figure 6a). Increase in the concentration of $\mathrm{NaCl}$ up to $25 \mathrm{~g} \mathrm{~L}^{-1}$ accelerated the degradation rate, enabling degradation of dye effluent (Figure $6 \mathrm{~b}$ ) to the extent of $95.54 \%$ decolourisation efficiency in 4 hrs. A further increase in $\mathrm{NaCl}$ concentration $\left(>25 \mathrm{~g} \mathrm{~L}^{-1}\right)$ there was a slight improvement in
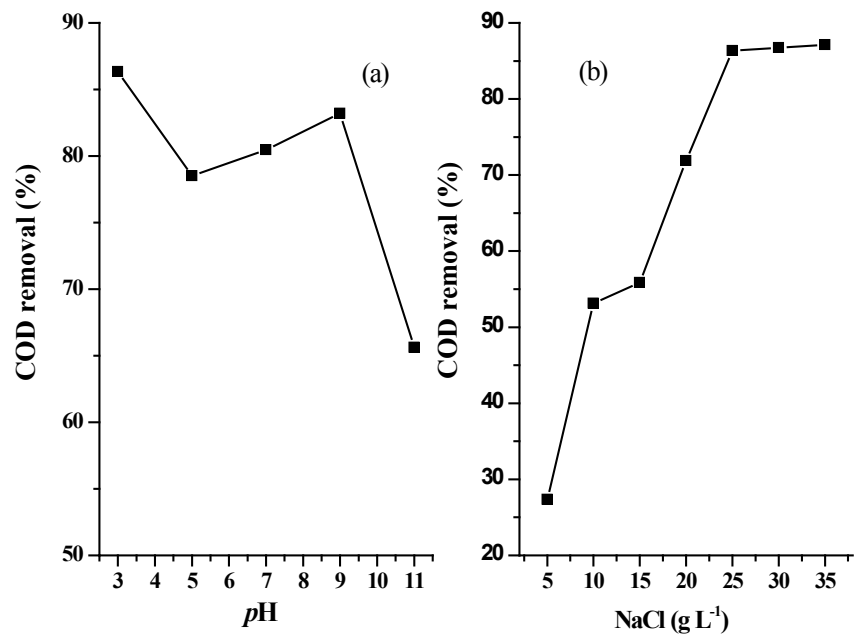

Figure 7: Effect of (a) $p^{H}$ and (b) $\mathrm{NaCl}$ concentration on removal of COD.

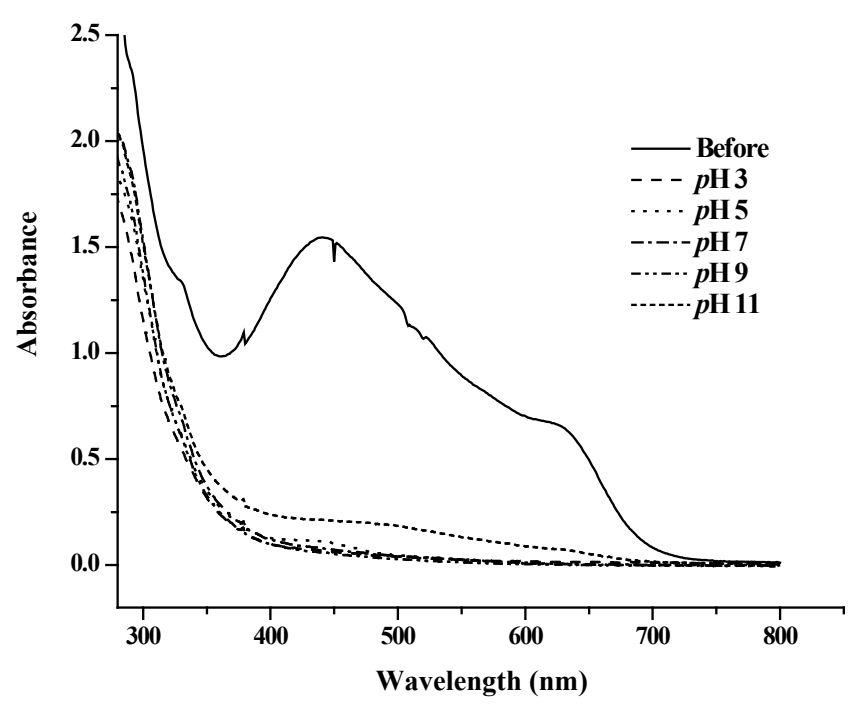

Figure 8: Absorption spectra for textile effluent before and after electrolysis (4 hrs) at different $p^{H}$ in $\mathrm{NaCl} 25 \mathrm{~g} \mathrm{~L}^{-1}$.

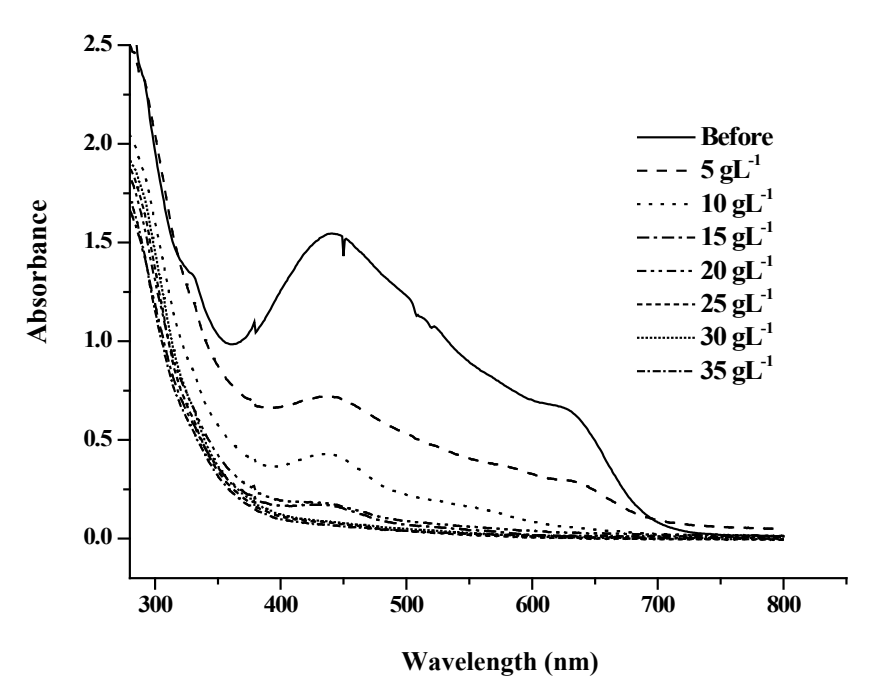

Figure 9: Absorption spectra for textile effluent before and after electrolysis (4 hrs) at different concentration of $\mathrm{NaCl}$ keeping constant $p^{H} 3$

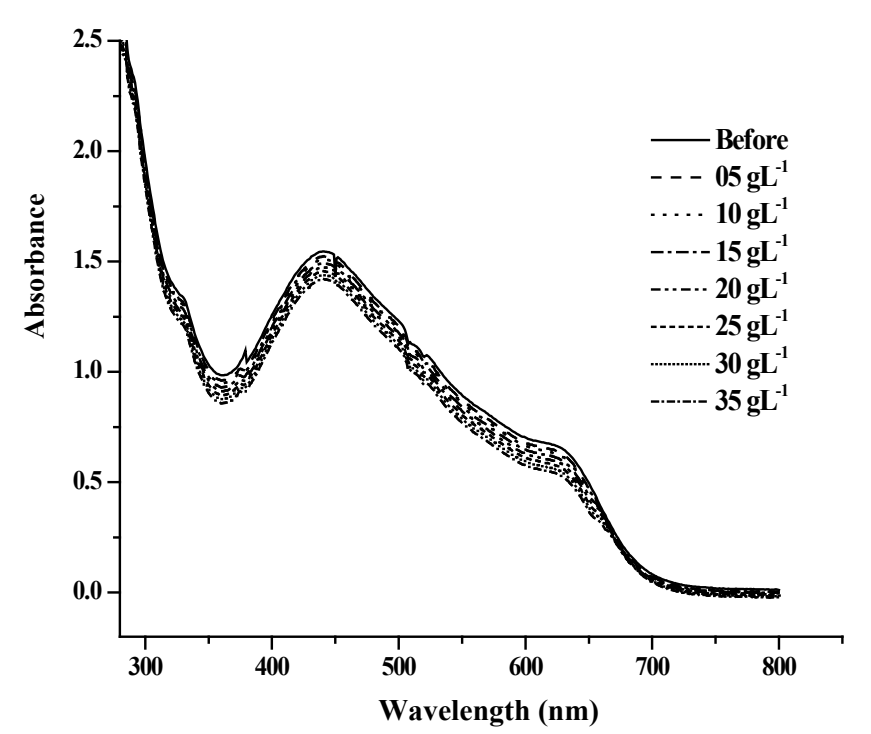

Figure 10: Absorption spectra for textile effluent before and after electrolysis $(4 \mathrm{hrs})$ at different concentration of $\mathrm{Na}_{2} \mathrm{SO}_{4}$ keeping constant $p^{H} 3$.

decolourisation efficiency, so the optimal concentration of $\mathrm{NaCl}$ used in the successive experiments was $25 \mathrm{~g} \mathrm{~L}^{-1}$.

\section{Analysis of COD}

The standard COD measurement is known to be affected by a number of inorganic substances [24]. Of these, chloride may have the significant effect on the test which is due to its reaction with potassium dichromate [25]. The COD was measured by adopting open reflux titrimetric method. In the present study it can be seen that the degradation of dye effluent may proceed by indirect electrochemical oxidation rather than direct electrochemical process. The electrolysis was carried out at a current density of $170 \mathrm{~A} \mathrm{~m}^{-2}$. At this current density, $\mathrm{Cl}_{2}$ generated in the solution drives the oxidation process. The $\mathrm{Cl}_{2}$ species is a powerful oxidizing agent capable of oxidizing the dyestuffs. In the absence of chloride containing electrolytes, the COD removal 
and dye effluent degradation efficiencies were very low [26]. The percent removal of COD increased with increase in the concentration of $\mathrm{NaCl}$ (Figure 7b). This confirmed that the electrogenerated chlorine/ hypochlorite will play an important role in the electrocatalytic degradation process of the dye-effluent. The maximum COD removal efficiency was observed at $p^{H} 3$ (Figure 7a).

\section{UV-vis spectra}

Typical UV-Visible spectra for untreated and treated dye effluent have been done and changes in absorbance of dye effluent were recorded (Figure 8 to 10). The initial spectra of dye effluent showed that the wavelength of maximum absorbance $\left(\lambda_{\max }\right)$ was at $440 \mathrm{~nm}$ in the visible region and corresponds to presence of chromopHores (colour producing) groups. In order to perceive distinctions between intermediates and initial dye effluent absorbance was monitored during the electrochemical degradation processes. The maximum decolouration of effluent was observed in 4 hours of electrolysis at $p^{H}$ 3 (Figure 8). At pH 3 active chlorine species hypochlorous acid will be generated which oxidizes the effluent effectively. The intensity of optical density at $\lambda_{\max }$ was decreased with increase in the concentration of $\mathrm{NaCl}$ (Figure 9). The degradation efficiency was found to be low in presence of $\mathrm{Na}_{2} \mathrm{SO}_{4}$ (Figure 10). During electrochemical degradation,

MS Spectrum

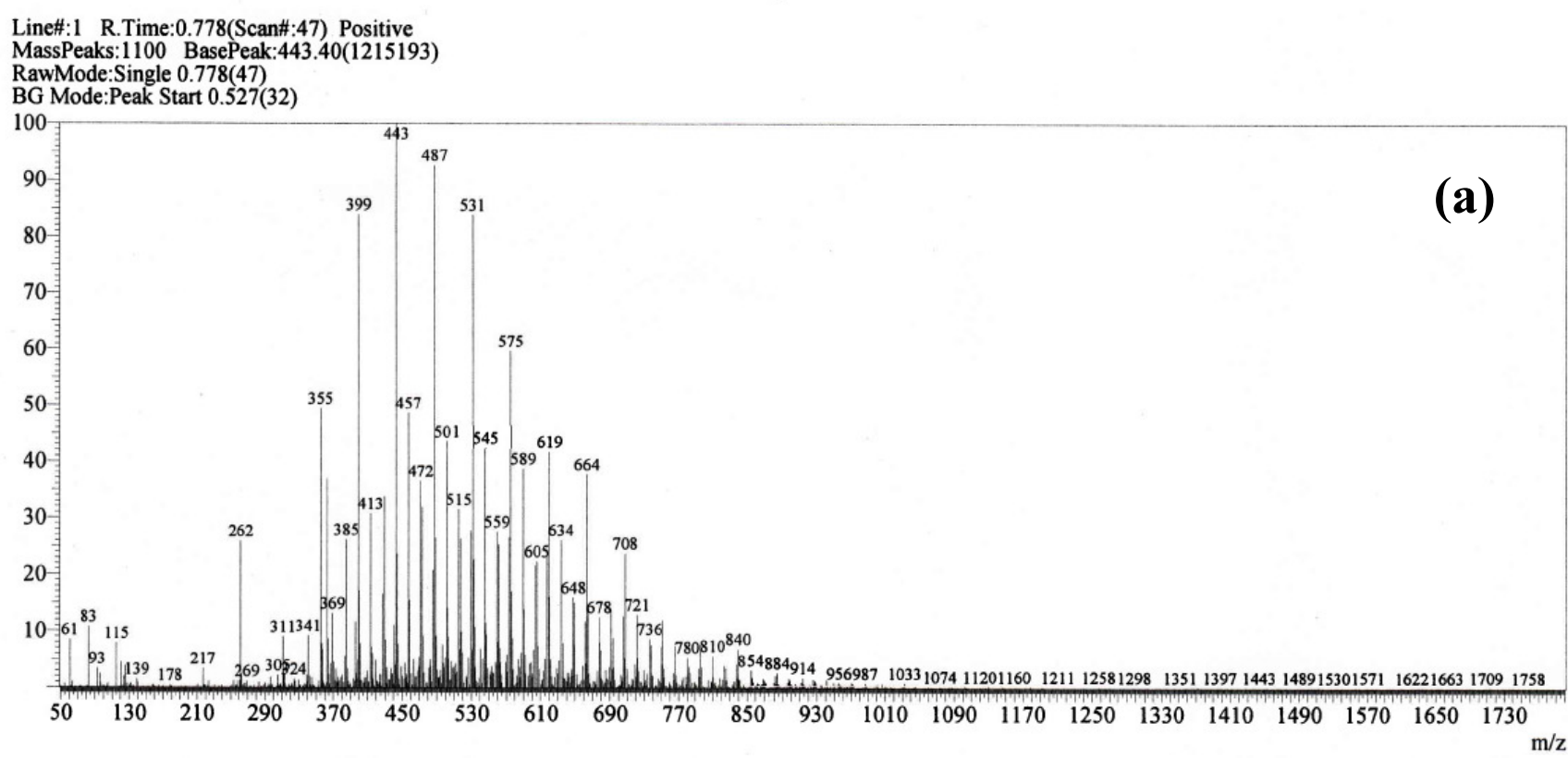

MS Spectrum

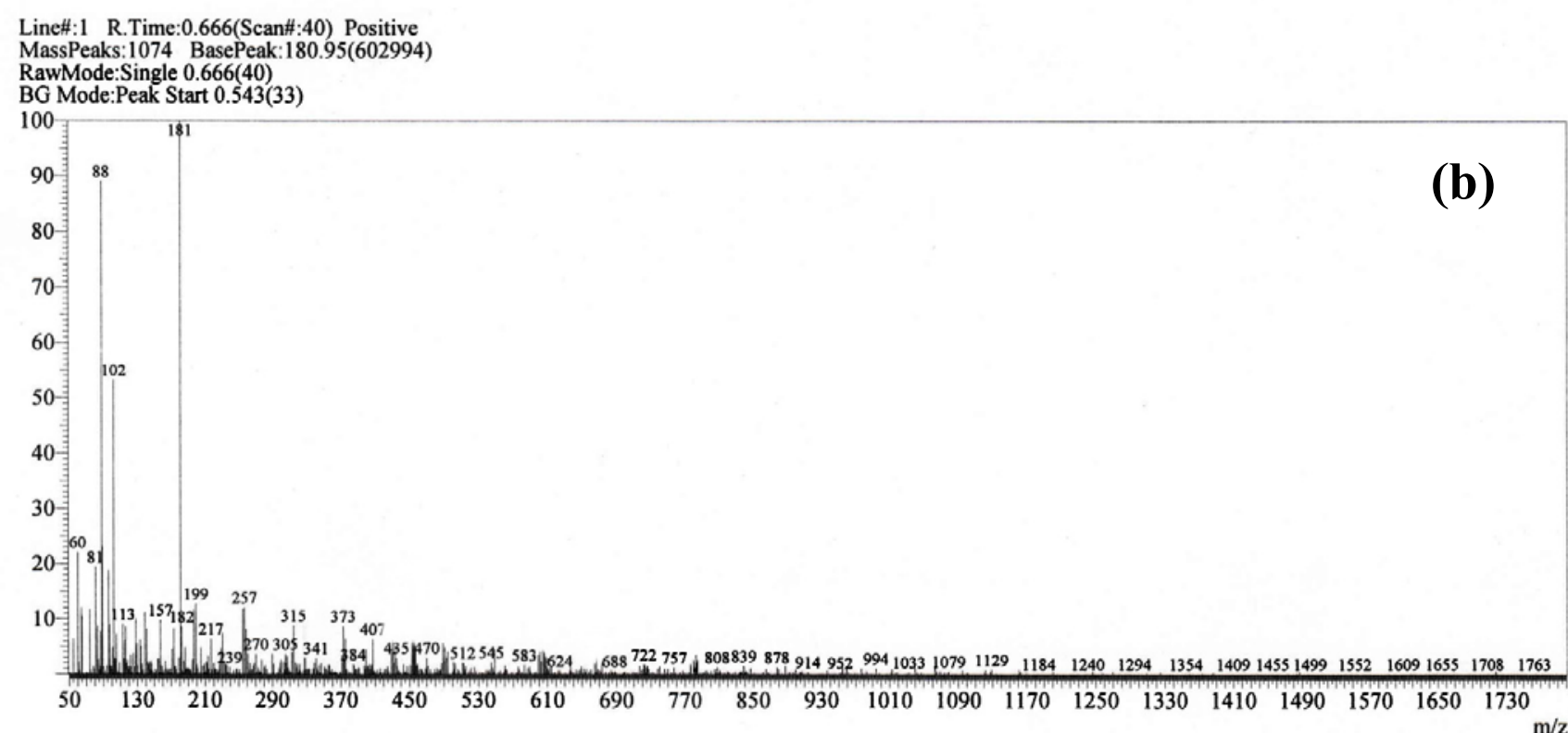

Figure 11: Mass spectrum of textile effluent (a) before electrolysis and (b) after electrolysis at the operational conditions of $p^{H:}: 3 ; \mathrm{NaCl}_{25} \mathrm{~g} \mathrm{~L} \mathrm{~L}^{-1} ; \mathrm{current}^{-}$density: $170 \mathrm{~A}$ $\mathrm{m}^{-2}$; time: 4 hrs. 


\begin{tabular}{|l|l|l|l|}
\hline Current $(\mathrm{A})$ & $\begin{array}{l}\text { Current } \\
\text { density }\left(\mathrm{Am}^{-2}\right)\end{array}$ & $\begin{array}{l}\text { Electrolysis time } \\
(\mathrm{hrs})\end{array}$ & $\begin{array}{l}\text { Energy Consumption }(\mathrm{k} \\
\left.\mathrm{W} \mathrm{h} \mathrm{m}^{-3}\right)\end{array}$ \\
\hline 0.10 & 085 & 4.00 & 07.060 \\
\hline 0.20 & 170 & 4.00 & 14.640 \\
\hline 0.30 & 255 & 4.00 & 29.760 \\
\hline 0.40 & 340 & 4.00 & 40.800 \\
\hline 0.50 & 425 & 4.00 & 63.000 \\
\hline
\end{tabular}

Table 1: The electric energy consumed during degradation of diluted textile effluent $\left(p^{H} 3\right)$ at various current densities.

the cleavage of chromophoric groups present in the textile effluent has taken place, which results in the decrease of optical density of the effluent. Also the absorption band has been shifted from visible to UV region, which indicated the degradation of large dye molecules (present in the effluent) into smaller fragments [27]. However, the active chlorine can lead the partial mineralisation of dye effluents [28].

\section{LC-MS studies}

LC-MS technique was employed to monitor the diminution in mass fragments of dyes molecules present in the effluent before and after electrolysis. Since this technique is specifically useful to study the degradation of dye effluent as well as the formation of intermediates, the decolourisation produced during the electrolysis. Before electrochemical treatment MS spectrum shows more number of peaks due to the presence of other impurities (Figure 11a). The MS spectrum of electrolysed dye effluent shows the absence of majority of earlier peaks, indicated that the entire dye effluent has been decomposed to colorless low molecular weight fragments (Figure 11b). The remaining peaks in the mass spectra may be due to the presence of simple aromatic compounds, particularly different substituted benzene moieties.

\section{Electric energy consumption}

The major operating cost is associated with the electrical energy consumption during electrochemical degradation process. The electrical energy consumption (E) is required to decompose diluted textile dye effluent at various current densities was calculated using the relation:

$$
E=\frac{V I t_{E}}{V_{s}} \times 10^{-3}
$$

where $E$ is the electrical energy consumption $\left(\mathrm{kWhm}^{-3}\right), V$ is the applied voltage $(\mathrm{V}), I$ is the applied current $(\mathrm{A}), t_{E}$ is the electrolysis time (h) and $V_{s}$ is the volume of dye effluent $\left(\mathrm{m}^{3}\right)$. As per the results the minimum electrical energy consumption was $14.640 \mathrm{k} \mathrm{W} \mathrm{h} \mathrm{m}^{-3}$ for dye effluent at $170 \mathrm{~A} \mathrm{~m}^{-2}$ current density. At higher current densities, the energy consumption was found to be increased (Table 1), which may be attributed to the increased hydrogen and oxygen evolution reactions.

\section{Conclusion}

In the present work the electrochemical degradation of textile effluent by using graphite carbon as anode and cathode, in the optimal operational electrolytic conditions (current density $170 \mathrm{~A}$ $\mathrm{m}^{-2}, \mathrm{NaCl}$ concentration $25 \mathrm{~g} \mathrm{~L}^{-1}, p^{H} 3$ and temperature $300.15 \mathrm{~K}$ ) influences the degradation of dyeing intermediates. Increasing the initial $p^{H}$ and current density will lead to corresponding decrease in the effluent degradation. The effect of conducting salt clearly showed that, introduction of $\mathrm{Cl}^{-}$containing electrolytes could enhance the degradation efficiency of the effluent. Cyclic voltammograms indicated the quasi-reversible electrochemical nature of effluent. UV-Vis and
MS spectral studies confirmed that the proposed electrochemical degradation process could be effective method for the degradation of textile dye effluent.

\section{Acknowledgements}

The Authors are grateful to DBT, DST and UGC, New Delhi for the financial support extended. Also grateful to Kuvempu University, Power Cell Battery India Limited and Himatsingka Linens, Karnataka for their support to carry out this work.

\section{References}

1. Venceslau MC, Tom S, Simon JJ (1994) Characterization of textile wastewatersa review Environmental Technology 15: 917- 929.

2. Adel A, Azni I, Katayon S, Chuah TG (2004) Treatment of Textile wastewater by Advanced Oxidation Processes - A Review. Global Nest: the Int J 6: 222-230.

3. Korbahti BK (2007) Response surface optimization of electrochemical treatment of textile dye wastewater. J Hazard Mater 145: 277-286.

4. Radha KV, Sridevi V, Kalaivani K (2009) Electrochemical oxidation for the treatment of textile industry wastewater. Bioresour Technol 100: 987-990.

5. Mohan N, Balasubramanian N, Ahmed BC (2007) Electrochemical oxidation of textile wastewater and its reuse. J Hazard Mater 147: 644-651.

6. Hao OJ, Kim H, Chiang PC (2000) Decolorization of wastewater Critical review Environ. Sci Technol 30: 449-505

7. Fernandes A, Morao A, Magrinho M, Lopes A, Goncalves I (2004) Electrochemical degradation of C.I. Acid Orange 7 Dyes Pigments 61: 287-296.

8. Sakalis A, Mpoulmpasakos K, Nickel U, Fytianos K, Voulgaropoulos V (2005) Evaluation of a novel electrochemical pilot plant process for azodyes removal from textile wastewater. Chem Eng J 111: 63-70.

9. Gutierrez MC, Crespi M (1999) A review of electrochemical treatments for colour elimination. J Soc Dyers Colourists 115: 342-345.

10. Lorimer JP, Mason TJ, Plattes M, Phull SS, Walton DJ (2001) Degradation of dye effluent Pure Appl Chem 73: 1957-1968.

11. Anastasios S, Dana A, Michal H, Pavel J, Anastasios V (2004) Analysis of sulpHonated azodyes and their degradation products in aqueous solutions treated with a new electrochemical method. Intern J Environ Anal Chem 84 875-888.

12. Daneshwar N, Sorkhabi HA, Kobya M (2004) Decolorization of Dye Solution Containing Acid Red 14 by Electrocoagulation with a Comparative Investigation of Different Electrode Connections J Hazard Mater 12: 55-62.

13. Sheng HL, Chi FP (1994) Treatment of textile wastewater by electrochemica method. Water Res 28: 277-282.

14. Iniesta J, Michaud PA, Panizza M, Comninellis Ch (2001) Electrochemical oxidation of 3-Methylpyridine at a boron-doped diamond electrode: application of electroorganic synthesis and wastewater treatment Electrochemistry Communication 3: 346-351.

15. Ricardo E, Palma G, Fernando L, Guzman D, Gustavo P (2010) Electrochemica degradation of crystal violet with BDD electrodes: Effect of electrochemical parameters and identification of organic by-products ChemospHere 81: 26-32

16. Vlyssides AG, Loizidou M, Karlis PK, Zorpas AA, Papaioannou D (1999) Electrochemical oxidation of a textile dye wastewater using a $\mathrm{Pt} / \mathrm{Ti}$ electrode. $\mathrm{J}$ Hazard Mater 70: 41-52.

17. Vlyssides AG, Papaioannou D, Loizidoy M, Karlis PK, Zorpas AA (2000) Testing an electrochemical method for treatment of textile dye wastewater Waste Manage 20: 569-574.

18. Naumczyk J, Szpyrkowicz L, Zilio-Grandi F (1996) Electrochemical treatment of textile wastewater. Water Sci Technol 34: 17-24.

19. Bahadır KK, Abdurrahman TA (2009) Continuous electrochemical treatment of simulated industrial textile wastewater from industrial components in a tubular reactor. J Hazard Mater 170: 771-778.

20. Kariyajjanavar P, Narayana J, Nayaka YA, Umanaik M (2010) Electrochemica Degradation and Cyclic Voltammetric Studies of Textile Reactive Azo Dye Cibacron Navy WB Portugaliae. Electrochimica Acta 28: 265-277. 
Citation: Kariyajjanavar P, Narayana J, Nayaka YA (2011) Degradation of Textile Wastewater by Electrochemical Method. Hydrol Current Res 2:110. doi:10.4172/2157-7587.1000110

Page 7 of 7

21. Szpyrkowicz L, Naumczyk J, Zilio-Grndi F (1995) Electrochemical Treatment of Tannery Wastewater using Ti/Pt and Ti/Pt/lr. Electrodes Wat Res 29:517-524.

22. Hasnain Isa M, Lee SL, Faridah AHA, Hamidi AA, Ramli NA, et al. (2007) Low cost removal of disperse dyes from aqueous solution using palm ash Dyes and Pigments 74: 446-453.

23. Hongzu M, Bo W, Xiaoyan L (2007) Studies on degradation of Methyl Orange wastewater by combined electrochemical process. J Hazard Mater 149: 492-498.

24. Lenor SC, Arnold EG, Andrew DE (1999) Standard Methods for the Examination of Water and Wastewater (20thedn) APHA/AWWA/WEF Washington DC USA.

25. Efthalia C, Nikolaos PX, Alberto C, Nicolas K, Dionissios M (2006)
Electrochemical treatment of textile dyes and dyehouse effluents. J Hazard Mater 137: 998-1007.

26. Abu Ghalwaa NM, Abdel-Latif MS (2005) Electrochemical Degradation of Acid Green Dye in Aqueous Wastewater Dyestuff Solutions Using a Lead Oxide Coated Titanium Electrode. J Iran Chem Soc 2: 238-243.

27. Fatiha A, Mouffok R. G, Mohamed B, Ahmed A, Jean-Louis B (2006) Bleaching and Degradation of Textile Dyes by Nonthermal Plasma Process at AtmospHeric Pressure Ind. Eng Chem Res 45: 23-29.

28. Fenyun Y, Shuixia C, Chan'e Y (2008) Effect of activated carbon fiber anode structure and electrolysis conditions on electrochemical degradation of dye wastewater. J Hazard Mater 157: 79-87. 